\title{
Ethnobotany of medicinal plants used to treat malaria by traditional healers from ten indigenous Colombian communities located in Waupes Medio
}

\begin{abstract}
The indigenous communities from Vaupes Medio possess knowledge in the use of plants to treat their illnesses. This knowledge has been transmitted orally from generation to generation. The present article aimed to carry out investigates the ethnobotany of medicinal plants used to cure malaria by 10 knowledgeable indigenous communities from Vaupes Medio, Colombia. Open and semi-structured interviews were conducted with 33 traditional healers representing 10 indigenous communities located in the Colombian southeast. Concurrently, field trips were conducted to identify and collect the reported species. Together with the aid of a bibliography, the identification and gathering of information for each species was performed in the Colombian Amazonian Herbarium - COAH - Sinchi Institute, Colombian National Herbarium (COL) and University of Antioquia Herbarium (HUA) herbariums. To find the relative importance of each plant species used to treat malaria, the degree of consensus among the survey respondents was determined using the Friedman's index. The traditional healers reported 41 morphospecies, among them 35 were identified down to the species, 5 to the genus, and 1 to the family. Notably, only we have reported 28 of these morphospecies for antimalarial use. Also, the plants that presented a major relative importance were Abuta grandifolia, Aspidosperma excelsum, Matisia cf. glandifera and Pleonotoma jasminifolia. Despite social and cultural changes favoring the rapid decline of ancestral knowledge, these indigenous communities located in the southeast of Colombia, have still managed to conserve their knowledge and use of traditional medicine to cure malaria.
\end{abstract}

Keywords: tradicional medicine, antimalarial plants, cubeo, ethnobotany, vaupés medio, colombia, ethnopharmacology
Volume I Issue 4 - 2017

\author{
Ramírez O,' Blair S, ' Vaupés Medio TV,2 \\ Cardona $F^{3}$ Pabón $A^{\prime}$ \\ 'Malaria Group, Faculty of Medicine, University of Antioquia, \\ Colombia \\ ${ }^{2}$ Knowledgeable group of traditional healers,Vaupés Medio, \\ Colombia \\ ${ }^{3}$ Group of Botanical Studies, University of Antioquia, Colombia
}

Correspondence: Adriana Pabón, Grupo Malaria, Facultad de Medicina, Universidad de Antioquia, Medellín, Colombia,Tel (574)2196490,Email apabon72@gmail.com

Received: August 08, 2017 | Published: November 28, 2017

\section{Introduction}

Globally, malaria or paludism is a grave public health problem. About 3.2billion people remain at risk of malaria. Annually, it produces between 149-303million clinical cases and kills more than 400,000 people. Among those killed, $90 \%$ are children under 5years old. ${ }^{1}$ In Latin America, the transmission of paludism is found in nine countries sharing the amazon forest region and in 8 countries representing the Caribbean and Central America. ${ }^{2}$ For Colombia in 2016, 83356 cases of malaria were reported to the National Health Institute (INS) through the Public Health Surveillance System (Sivigila), and the distribution by species corresponded to 47497 cases (57\%) by P. falciparum, followed by $P$. vivax with 33055 cases (39.7\%) and 2804 cases (3.3\%) of mixed infections (P. falciparum and $P$. vivax). In addition, 19 deaths were confirmed because of this disease in Colombian territory. ${ }^{3}$ These data show the importance of this disease in the panorama of morbidity and mortality at local and global level.

Natural or vector borne infection in humans is by six species from the genus Plasmodium: P. falciparum, P. vivax, P. ovale, P. malariae, $P$. knowlesi, ${ }^{1}$ and recently $P$. cynomolgi. ${ }^{4}$ This parasite is transmitted to humans by the bite of the Anopheles mosquito. Once inside the organism, the parasite causes clinical symptoms that can range from mild to grave, or even lead to fatal., ${ }^{5,6}$ Traditional medicine uses plants to treat different illnesses, and their use is so efficient that the World Health Organization (WHO) estimates that $80 \%$ of the world population uses plants as alternative therapy. ${ }^{7}$ Since 1670 , medical plants like Quina have been used to treat paludic feavers. It was not until 1820 that two French chemists, Pierre Pelletier and Joseph Caventou isolated a metabolite called quinina from this plant. Quinina served as a template for the synthesis of the aminochinolines such as cloroquine, which was used as a first-line medicine until 1971 when the first cases of $P$. falciparum resistance appeared ${ }^{8}$ This stimulated the search for new antimalarial agents. In 1972 Chinese scientists isolated artemisinin from the Artemisa anua plant. This permitted the synthesis of the artemisinin derivatives artesunate, arteheter, artemether, constituting a new pilar of antimalarial therapy. ${ }^{9,10}$

Latin America is a region both endemic to malaria and to some of the most diverse ecosystems in the world. One third of the worlds species are found in Latin American tropical rain forests. ${ }^{11}$ Concurrenty, there exists a wide cultural diversity linked to traditional knowledge from different South American ethnic groups. This diversity has been affected and threatened by colonization which began in the 15 th century and advanced in the 20th century. ${ }^{12}$ In the case of Vaupes medio, it was due to the bonanaza of rubber, coca farming, and the sale of animal skins. These processes led to deforestation and an alteration in social structure, bringing about a loss of plant diversity and of the knowledge associated with it. ${ }^{13}$

Among the indigenous and mestizo communities located in the Vaupes Department of the southeastern part of Colombia, the population is $85 \%$ indigenous representing 27 ethnic groups. Among 
those groups, the most numerous are: Cubeo, Tucano, Desano and Guanano. ${ }^{14}$ These communities are effected by malaria, above all, those which are located in the Vaupés Alto, Vaupés Medio, Papunahua, Apaporis river, and at the Querarí river head. In this zone, malaria has been treated by diverse traditional healers from the region using medicinal plants (for preventing it or curing it). Nevertheless, these practices are disappearing due to the social phenomena explained previously.

The purpose of this study is to contribute to and preserve the ancestral knowledge related to medicinal use of plants among the communities located in the Vaupés Medio. More specifically, information was collected about medicinal plants used to cure malaria from 33 indigenous traditional healers from this zone. In the presence of the healers, plants were identified and collected. They were later studied taxonomically and the greater frequency of use was determined by the Friedman's index.

\section{Materials and methods}

\section{Study area}

An area of 10,901.56 hectares located within the town of Mitú, the Capital of the Department of Vaupés Medio, in the Vaupés Medio zone, was chosen as the study area (Figure 1). This area includes 10 indigenous communities with 1260 inhabitants distributed as demonstrated in Table 1. According to the Holdridge classification, this region is located within the Tropical Rain Forest life system zone, between 185 to 205 meters above sea level, with an average temperature of $25.7^{\circ} \mathrm{C}, 3000 \mathrm{~mm}$ maximum annual rain fall, relative humidity is always above $80 \%$, and the sun shines on average 1,255 hours annually. ${ }^{15}$

Table I Geographical characteristics of the ten communities in the Middle Vaupes

\begin{tabular}{|c|c|c|c|c|}
\hline Community & $\begin{array}{l}\text { Number of } \\
\text { inhabitants* }\end{array}$ & Geographical coordinates & $\begin{array}{l}\text { Number and \% of } \\
\text { collaberators }\end{array}$ & $\begin{array}{l}\text { Reported } \\
\text { plants }\end{array}$ \\
\hline Bella Vista del Tuy & 85 & $0^{\circ} 43^{\prime} 25.29^{\prime \prime} \mathrm{N}$ and $70^{\circ} 54^{\prime} 50^{\prime \prime} \mathrm{O}$ & $2(6.06)$ & 2 \\
\hline Nueva Florida & 57 & $0^{\circ} 50^{\prime} 24.86^{\prime \prime} \mathrm{N}$ and $70^{\circ} 56^{\prime} 47.98^{\prime \prime} \mathrm{O}$ & $4(12.12)$ & 6 \\
\hline Puerto Laguna & 105 & $0^{\circ} 48^{\prime} \mathrm{I} I .09^{\prime \prime} \mathrm{N}$ and $70^{\circ} 57^{\prime} .16 .20^{\prime} \mathrm{O}$ & $9(27.27)$ & 19 \\
\hline San José de Ñamú & 186 & $0^{\circ} 55^{\prime} 44.89^{\prime \prime} \mathrm{N}$ and $70^{\circ} 33^{\prime} .24 .80^{\prime} \mathrm{O}$ & $2(6.06)$ & 6 \\
\hline Yuruparí & 240 & $0^{\circ} 5 \mathrm{I} ' 56.68^{\prime \prime} \mathrm{N}$ and $70^{\circ} 59^{\prime} .56 .68^{\prime \prime} \mathrm{O}$ & $6(18.18)$ & 13 \\
\hline San Miguel de los Cerros & 84 & $0^{\circ} 52^{\prime} 46.24^{\prime \prime} \mathrm{N}$ and $70^{\circ} 43^{\prime} 18.19^{\prime \prime} \mathrm{O}$ & $2(6.06)$ & 4 \\
\hline San Pablo de Mandí & 171 & $I^{\circ} 05^{\prime} 59.17^{\prime \prime} \mathrm{N}$ and $70^{\circ} 43^{\prime} \mid 0.3 I^{\prime \prime} \mathrm{O}$ & $2(6.06)$ & 4 \\
\hline San Pedro del $\mathrm{Ti}$ & 127 & $0^{\circ} 48^{\prime} 05.68^{\prime \prime} \mathrm{N}$ and $70^{\circ} 42^{\prime} 01.97^{\prime \prime} \mathrm{O}$ & I (3.03) & 0 \\
\hline Santa Rosa de Lima & 84 & $0^{\circ} 57^{\prime} 35.6 \mathrm{I} " \mathrm{~N}$ and $70^{\circ} 4345,55^{\prime \prime} \mathrm{O}$ & $\mathrm{I}(3.03)$ & I \\
\hline Nazaret del $\mathrm{Ti}$ & 121 & $0^{\circ} 5 \mathrm{I} 24.50^{\prime \prime} \mathrm{N}$ and $70^{\circ} 4 \mathrm{I}^{\prime} 3 \mathrm{I} .46^{\prime \prime} \mathrm{O}$ & $3(9.09)$ & 2 \\
\hline Total & & & $33(100)$ & 57 \\
\hline
\end{tabular}

*Data reported by Felipe Rodriguez, the indigenous president of the Association of Traditional Authorities Middle Vaupes (ATTIVAM) in 20I0.Altitude (m.s.n.m), 180

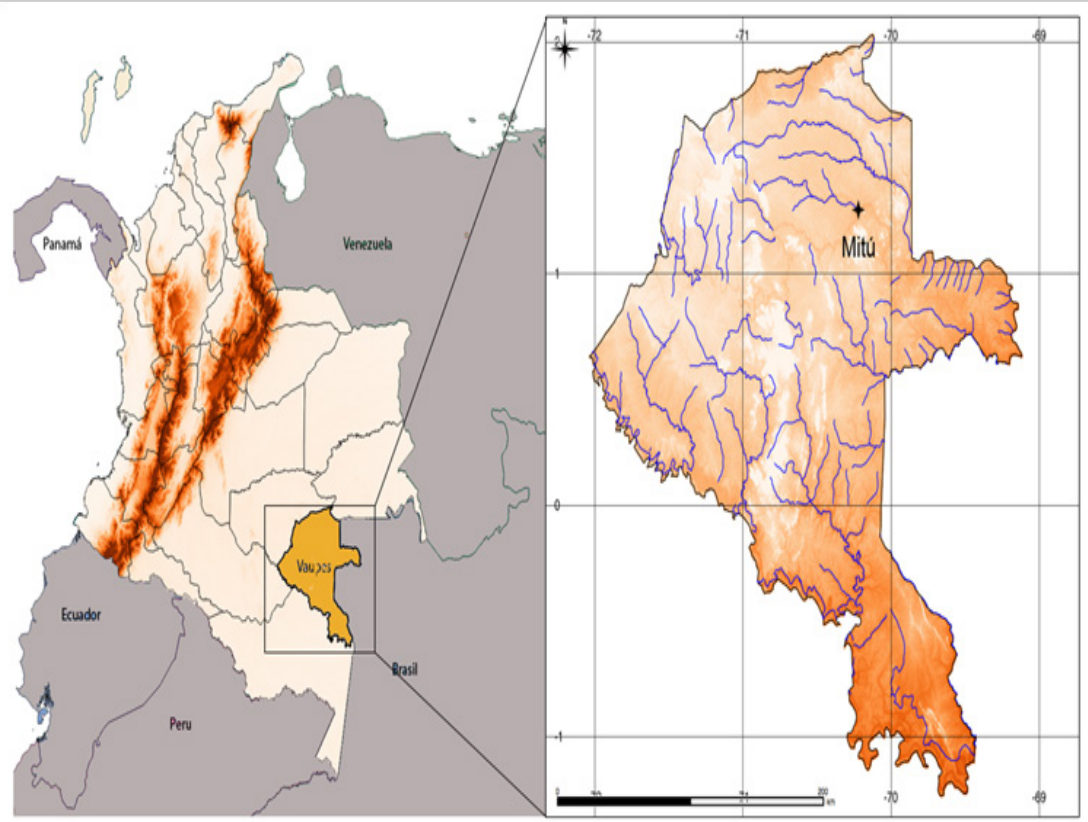

Figure I Geographical location of the study area. 
The rainy season is between March and July, with monthly precipitations that oscillate between 250 and $300 \mathrm{~mm}$. The least rainy period occurs between August and October and is called "Indian summer or time of the worm". The dry period occurs between November and February. The indigenous communities studied can be found between tributaries of the creeks Ti and Tui on the shores of the Vaupés river, known specifically as the Vaupés Medio. In this region located between Pucarón and Yacayacá, there are 22 indigenous communities with approximately 2684 inhabitants, belonging mostly to the ethnic groups: Tatuyo, Carapana, Cubeos, Guananos, Piratapuyos, Tuyuka and Tukano. Additionally, there are small populations of ethnic groups representing the Siriano, Yurutí, Barazano, Makuna, Pisamira, Taiwano, and Desanos peoples, as well as non-indigenous people, all members of the Traditional Indigenous Association of Vaupés Medio (ATTIVAM). The majority of these ethnic groups are not found within their ancestral territories, displaced from other Amazonian territories due to the phenomenon of rubber harvesting (Felipe Rodriguez, Personal communication, 2006.). The indigenous economy in this zone is subsistence, coming from agricultural activities known as "chagras" or small plantations, fishing, hunting and collection of wild species. ${ }^{16}$

\section{Ethics}

Initially, the researchers informed the community of the objectives and expectations of the study and invited the traditional healers to participate. The key informants who offered to participate read the informed consent, if they could not read; it was translated to Cubeo and read to them. The translator is the first author of this work, is indigenous Cubeo and is knowledgeable of some dialects spoken in the zone. Subsequently, the informed consent was signed and in the case of those who did not know how to sign, their finger print was used. The informed consent had the approval of the Bioethical Committee from the Medical Research Institute within the Medical School of the University of Antioquia.

\section{Coordination with the community}

At the 2007 congress of the indigenous organization of Vaupés Medio, the first contact with the communities in this zone was made. Attending were approximately 70 people, among them leaders and inhabitants from the community, permitting a space for discussion and knowledge sharing. Additionally, consent for the collection of information for the study was obtained. During this event the study design and proposal was presented to traditional authorities. During the presentation, it was highlighted the benefits and importance of recovering the oral knowledge of traditional antimalarial medicinal plants, and conserving it by recording it in the books. Once consent was obtained and the work consolidated with the communities, each community was visited in search of the key partners.

In conclusion of the conciliation process, communities expressed their interest in the project and signed agreements between themselves and researchers of the University of Antioquia. The indigenous authorities recognized the project as an opportunity to gather and preserve the oral tradition of medicinal plants used to cure malaria. Ultimately, they desire to give ownership of this knowledge to the younger generations so that it is not lost over time.

\section{Traditional healer selection}

The key traditional healers were chosen according to participant observation. ${ }^{17-23}$ More specifically, the snowball or avalanche sampling approach was used, ${ }^{24}$ under the premise that the members of the population know each other and can identify which other person from the indigenous community to interview. Additionally, the following criteria were considered: living within the study area, to be recognized by their inhabitants as traditional healers, cure malaria with plants or prayers. In this context, 30 men and 3 women between the ages of 22 and 62 years old were chosen.

\section{Ethnobotanical survey}

Open interviews, semi-structured interviews and ethnobotanical walks were conducted with 33 traditional healers ( 31 indigenous and 2 belonging to a group of mestizos known as "cabuco", according to the methodology described by Cunnigham..$^{25,19,25,26}$ They collected information about:

i. Description and identification of plants used for treating malaria in their natural habitat

ii. Detailed description of each plant collection process (hour, station, place, among others)

iii. Part of the plant used (bark, root and leaf) and mode of preparation (infusion, decoction and etc.)

iv. Recipe directions and warnings

v. Overview of the illness (causes, diagnosis, prevention and treatments to cure and prevent it)

During the walks, with each traditional healer, specimens following the described methodology (Appendix A) were collected and photographed. This material and the botanical samples were used in the identification of the species.

\section{Species characterization}

The botanical samples were sent to the Universidad de Antioquia Herbarium (HUA) and in some cases they were referred to the Colombian Amazon Herbarium (COAH) to be characterized. The process was supported by specialized literature about the topic, data bases of images and collections from other herbariums. One sample of each collected species was stored in the HUA herbarium as a reference. Additionally, ethnobotanical information of each reported species was recorded in files stored in the herbariums COAH, COL and HUA.

\section{Data analysis}

With the purpose of identifying the most popular species among the 10 surveyed communities, the Friedman index was implemented:

$$
\mathrm{FI}=\frac{\mathrm{I}_{\mathrm{p}}}{\mathrm{I}_{\mathrm{t}}} \times 100
$$

Where,

$\mathrm{I}_{\mathrm{p}}$ : Is the number of traditional healers that mention the use or knowledge of some given species (frequency of citation)

\section{$\mathrm{I}_{\mathrm{t}}$ : Is the total number of traditional healers.}

According to this methodology, the species used for treating health problems which have a Friedman's index larger than 20\%, have a strong cultural acceptance among the communities and should be studied and validated by science. Friedman ${ }^{27}$ argues that species with strong cultural acceptance are more likely to be effective against illness, given the communities test over time. ${ }^{27}$ 


\section{Results}

The number of performed surveys in each community and their respective percentage can be found in Table 1 . Thirty (91\%) of the traditional healers are male. Eighteen (55\%) of 33 performed surveys reported information from the ethnic Cubeo, and the rest from Carapana, Desano, Yuruti, Guanano and Mestizo groups. Among all the traditional healers, only one payé (shaman) from Puerto Laguna community was interviewed.

\section{Description about the role of traditional healers wi-} thin the middle vaupés indigenous communities

The payé is a traditional healer and shaman from the Vaupés aboriginal societies that has magical powers and establishes a relationship with the supernatural world. He has knowledge about the community's myths, treatments for illness and witchcraft practices. $\mathrm{He}$ is the master of a universe inhabited by spirits, and at the same time is a healer, protector of the community and exorcist. He reaches some level of trance to establish a connection with the supernatural universe in which one or more spirits are in his favor, hears his requests and assists him to practice good or evil. He is able to diagnose an illness, foresee the fate of the sick person and fight against witchcraft and other cultural ailments. Historically, in the Vaupés region the payé uses the aid of sacred plants like yage and yopo, to reach the psychological states of mind to communicate with the supernatural universe. ${ }^{28}$

The payé is the community member who knows more about illnesses, the diagnosis and treatment techniques, and to some extent, the use of medicinal plants. Additionally, in some occasions, is the only person in charge of diagnosing, preventing and treating the illnesses of some communities which are beyond the reach of the state health programs. In addition to the payé, there are members in the community identified as traditional healers, they possess less knowledge than the payé, but also use plants to prevent and treat illness. However, they do not use sacred plants to reach a different psychological state of mind, nor are able to establish communication with the supernatural universe to be favored by the spirits.

\section{Reported species}

There were registered 41 morphospecies belonging to 37 genera, distributed in 25 families and locally labeled with 47 vernacular names (Table 2). Among the registered morphospecies 35 were identified down to species, 5 to genus, and one to family. The families with the larger number of genera and species were the Bignoniaceae ( 8 spices $/ 7$ genres) and Fabaceae (5 species/4 genres). The most frequent plant types for the antimalarial species were trees 19(46.34\%), followed by vines $12(29.26 \%)$, and in a less proportion, bushes $7(17.07 \%)$, herbs $2(4.87 \%)$ and palms $1(2.43 \%)$, Table 2. Among all 35 morphospecies identified down to the species, 31 are native to the region. The species Cosmos caudatus, Mangifera indica, Crescentia cujete and Citrus limon are introduced. $95.12 \%$ of the species grow wild (38) and three $(7.31 \%)$ are cultivated. The part of the plant most commonly used by the traditional healers of the Middle Vaupés region to fabricate the medicine is the stem bark. Decoction with water was identified as the only procedure for preparing the medicine. The traditional healers described two ways for administering the medicine, oral, according to Pérez, ${ }^{29}$ and in baths and ointments for preventing the disease.

Among the 35 identified species, only 13 had a previous record as antimalarian medicine: Abaremalaeta, Abuta grandifolia, Aspidosperma excelsum, Crescentia cujete, Guarea guidonia, Jacaranda copaia, Picrolemma sprucei, Doliocarpus dentatus, Potalia resinifera, Mangifera indica, Tabebuia serratifolia, Abuta rufescens and Citrus limón. This paper and just another us, ${ }^{30}$ introduces 28 plants, not previously mentioned by the literature, which are used as antimalarial medicine by the indigenous communities in the Middle Vaupés region. Their distribution is this: 23 were identified down to the species, 4 to genus and one to family. According to the Friedman's index (1996) (Table 2) the species with the most cultural importance are: Abuta grandifolia, Matisia cf. Glandifera, Pleonotoma jasminifolia and Aspidosperma excelsum.

Table $\mathbf{2}$ List of plants used by traditional healers Middle Vaupes, for the treatment of malaria

\begin{tabular}{|c|c|c|c|c|c|c|c|c|c|}
\hline Family & Species & $\begin{array}{l}\text { Numbers } \\
\text { of } \\
\text { voucher } \\
\text { specimen }\end{array}$ & $\begin{array}{l}\text { Number } \\
\text { of } \\
\text { Citations }\end{array}$ & $\begin{array}{l}\text { FI } \\
(\%)\end{array}$ & $\begin{array}{l}\text { Parte } \\
\text { used }\end{array}$ & $\begin{array}{l}\text { Plant } \\
\text { Type }\end{array}$ & Origen & $\begin{array}{l}\text { Cultural } \\
\text { State }\end{array}$ & $\begin{array}{l}\text { Other uses } \\
\text { reported } \\
\text { by the } \\
\text { traditional } \\
\text { healers }\end{array}$ \\
\hline Anacardiaceae & Mangifera indica L. & |2969| & I & 3 & Stem bark & Tree & Introduced & Cultivated & $\begin{array}{l}\text { To treat } \\
\text { diarrhea. }\end{array}$ \\
\hline Apocynaceae & $\begin{array}{l}\text { Aspidosperma } \\
\text { excelsum Benth. }\end{array}$ & 194115 & 2 & 6.1 & Stem bark & Tree & Native & Wild & $\begin{array}{l}\text { To soothe } \\
\text { toothaches } \\
\text { and make axe } \\
\text { handles. }\end{array}$ \\
\hline Arecaceae & Euterpe Spp. & & I & 3 & Root & Palm & Native & Wild & $\begin{array}{l}\text { snakebite } \\
\text { (coral) }\end{array}$ \\
\hline Asteraceae & $\begin{array}{l}\text { Cosmos caudatus } \\
\text { Kunth }\end{array}$ & & I & 3 & $\begin{array}{l}\text { Entire } \\
\text { plant }\end{array}$ & Grass & Introduced & Wild & $\begin{array}{l}\text { To treatment } \\
\text { of flu, measles } \\
\text { and whooping } \\
\text { cough }\end{array}$ \\
\hline
\end{tabular}


Table Continued.

\begin{tabular}{|c|c|c|c|c|c|c|c|c|c|}
\hline Family & Species & $\begin{array}{l}\text { Numbers } \\
\text { of } \\
\text { voucher } \\
\text { specimen }\end{array}$ & $\begin{array}{l}\text { Number } \\
\text { of } \\
\text { Citations }\end{array}$ & $\begin{array}{l}\text { FI } \\
\text { (\%) }\end{array}$ & $\begin{array}{l}\text { Parte } \\
\text { used }\end{array}$ & $\begin{array}{l}\text { Plant } \\
\text { Type }\end{array}$ & Origen & $\begin{array}{l}\text { Cultural } \\
\text { State }\end{array}$ & $\begin{array}{l}\text { Other uses } \\
\text { reported } \\
\text { by the } \\
\text { traditional } \\
\text { healers }\end{array}$ \\
\hline & \multicolumn{2}{|c|}{$\begin{array}{l}\text { Clytostoma binatum (Thunb.) } \\
\text { Sandwith }\end{array}$} & I & 3 & Stem bark & $\begin{array}{l}\text { Reed or } \\
\text { Liana }\end{array}$ & Native & Wild & $\begin{array}{l}\text { To treat } \\
\text { conjunctivitis. }\end{array}$ \\
\hline & $\begin{array}{l}\text { Arrabidaea } \\
\text { verrucosa }\end{array}$ & 194126 & 1 & 3 & Stem bark & $\begin{array}{l}\text { Reed or } \\
\text { Liana }\end{array}$ & Native & Wild & $\begin{array}{l}\text { Not } \\
\text { reported. }\end{array}$ \\
\hline & $\begin{array}{l}\text { Pleonotoma } \\
\text { jasminifolia (Kunth) } \\
\text { Miers }\end{array}$ & 194127 & 2 & 6.1 & Stem bark & $\begin{array}{l}\text { Reed or } \\
\text { Liana }\end{array}$ & Native & Wild & $\begin{array}{l}\text { Not } \\
\text { reported. }\end{array}$ \\
\hline & $\begin{array}{l}\text { Pleonotoma } \\
\text { variabilis (Jacq.) } \\
\text { Miers }\end{array}$ & 194107 & I & 3 & Stem bark & $\begin{array}{l}\text { Reed or } \\
\text { Liana }\end{array}$ & Native & Wild & $\begin{array}{l}\text { Not } \\
\text { reported. }\end{array}$ \\
\hline \multirow[t]{4}{*}{ Bignonaceae } & $\begin{array}{l}\text { Callichlamys latifolia } \\
\text { (Rich.) K. Schum. }\end{array}$ & 194120 & I & 3 & Stem bark & $\begin{array}{l}\text { Reed or } \\
\text { Liana }\end{array}$ & Native & Wild & $\begin{array}{l}\text { To treat } \\
\text { stomach } \\
\text { ailments, } \\
\text { epilepsy and } \\
\text { poisoning by } \\
\text { venom }\end{array}$ \\
\hline & Crescentia cujete L. & & I & 3 & Stem bark & Tree & Introduced & Cultivated & $\begin{array}{l}\text { The fruit is } \\
\text { used to make } \\
\text { totumas, a } \\
\text { type of gourd } \\
\text { used to make } \\
\text { vessels for } \\
\text { drinking or } \\
\text { eating }\end{array}$ \\
\hline & $\begin{array}{l}\text { Jacaranda copaia } \\
\text { (Aubl.) D. Don } \\
\text { subsp. spectabilis } \\
\text { (Mart. ex DC.) } \\
\text { A.H. Gentry }\end{array}$ & 194113 & 2 & 6.1 & Stem bark & Tree & Native & Wild & $\begin{array}{l}\text { To combat } \\
\text { pruritis } \\
\text { and skin } \\
\text { infections }\end{array}$ \\
\hline & \multicolumn{2}{|c|}{$\begin{array}{l}\text { Tabebuia serratifolia (Vahl) G. } \\
\text { Nicholson }\end{array}$} & 1 & 3 & Stem bark & Tree & Native & Wild & $\begin{array}{l}\text { To cure } \\
\text { rheumatism }\end{array}$ \\
\hline Bombacaceae & $\begin{array}{l}\text { Matisia cf. } \\
\text { glandifera Planch. } \\
\text { \& Triana }\end{array}$ & 194125 & 4 & 12.1 & $\begin{array}{l}\text { Stem bark, } \\
\text { Leafs }\end{array}$ & Tree & Native & Wild & $\begin{array}{l}\text { Not } \\
\text { reported. }\end{array}$ \\
\hline Caesalpiniaceae & $\begin{array}{l}\text { Senna spinescens } \\
\text { (Hoffmanns. ex } \\
\text { Vogel) H.S. Irwin } \\
\text { \& Barneby }\end{array}$ & 194115 & I & 3 & Stem bark & $\begin{array}{l}\text { Reed or } \\
\text { Liana }\end{array}$ & Native & Wild & $\begin{array}{l}\text { Not } \\
\text { reported. }\end{array}$ \\
\hline Clusiaceae & $\begin{array}{l}\text { Tovomita Cf. } \\
\text { spruceana }\end{array}$ & 194109 & I & 3 & Stem bark & Bush & Native & Wild & $\begin{array}{l}\text { Not } \\
\text { reported. }\end{array}$ \\
\hline Cyperaceae & $\begin{array}{l}\text { Rhynchospora nervos } \\
\text { Boeckeler }\end{array}$ & (Vahl) & I & 3 & $\begin{array}{l}\text { Flower } \\
\text { bud }\end{array}$ & Grass & Native & Wild & To flu remedy \\
\hline Dilleniaceae & $\begin{array}{l}\text { Doliocarpus } \\
\text { dentatus (Aubl.) } \\
\text { Standl. }\end{array}$ & 194111 & 1 & 3 & Sap & $\begin{array}{l}\text { Reed or } \\
\text { Liana }\end{array}$ & Native & Wild & $\begin{array}{l}\text { To soo the } \\
\text { headaches, } \\
\text { fever and } \\
\text { stomach pain. }\end{array}$ \\
\hline
\end{tabular}


Table Continued...

\begin{tabular}{|c|c|c|c|c|c|c|c|c|c|}
\hline Family & Species & $\begin{array}{l}\text { Numbers } \\
\text { of } \\
\text { voucher } \\
\text { specimen }\end{array}$ & $\begin{array}{l}\text { Number } \\
\text { of } \\
\text { Citations }\end{array}$ & $\begin{array}{l}\text { FI } \\
(\%)\end{array}$ & $\begin{array}{l}\text { Parte } \\
\text { used }\end{array}$ & $\begin{array}{l}\text { Plant } \\
\text { Type }\end{array}$ & Origen & $\begin{array}{l}\text { Cultural } \\
\text { State }\end{array}$ & $\begin{array}{l}\text { Other uses } \\
\text { reported } \\
\text { by the } \\
\text { traditional } \\
\text { healers }\end{array}$ \\
\hline \multirow{4}{*}{ Fabaceae } & $\begin{array}{l}\text { Clathrotropis } \\
\text { macrocarpa Ducke }\end{array}$ & 194109 & 3 & 9.1 & Stem bark & Tree & Native & Wild & $\begin{array}{l}\text { The leaves } \\
\text { of the tree } \\
\text { are used for } \\
\text { packaging } \\
\text { farina } \\
\text { (Amazon } \\
\text { cereal). The } \\
\text { stem bark } \\
\text { is applied } \\
\text { to the skin } \\
\text { to alleviate } \\
\text { itchiness } \\
\text { and as a } \\
\text { deodorant }\end{array}$ \\
\hline & Machaerium sp & & 1 & 3 & Sap & $\begin{array}{l}\text { Reed or } \\
\text { Liana }\end{array}$ & Native & Wild & $\begin{array}{l}\text { Among the } \\
\text { Cubeos, it is } \\
\text { used to treat } \\
\text { stomachaches } \\
\text { and } \\
\text { headaches. }\end{array}$ \\
\hline & \multicolumn{2}{|c|}{$\begin{array}{l}\text { Monopteryx uaucu Spruce ex. } \\
\text { Benth. }\end{array}$} & 1 & 3 & Stem bark & Tree & Native & Wild & Not reported \\
\hline & $\begin{array}{l}\text { Fabaceae } \\
\text { pagapunisuore }\end{array}$ & 194133 & 1 & 3 & Stem bark & Tree & Native & Wild & $\begin{array}{l}\text { To calm } \\
\text { headache, } \\
\text { fever and } \\
\text { stomach pain. }\end{array}$ \\
\hline Lauracea & $\begin{array}{l}\text { Anaueria } \\
\text { brasiliensis } \\
\text { Kosterm. }\end{array}$ & 194122 & I & 3 & Stem bark & Tree & Native & Wild & $\begin{array}{l}\text { The fruit is } \\
\text { used against } \\
\text { snakebites. }\end{array}$ \\
\hline Loganiaceae & $\begin{array}{l}\text { Potalia resinifera } \\
\text { Mart. }\end{array}$ & 194119 & 2 & 6.1 & Stem bark & Bush & Native & Wild & $\begin{array}{l}\text { For snake } \\
\text { bites and to } \\
\text { reduce fever }\end{array}$ \\
\hline \multirow[t]{2}{*}{ Malpighiaceae } & \multicolumn{2}{|c|}{ Byrsonima japurensis A. Juss. } & 1 & 3 & Stem bark & Tree & Native & Wild & $\begin{array}{l}\text { The fruit of } \\
\text { the plant is } \\
\text { used as bate } \\
\text { for fishing }\end{array}$ \\
\hline & Hiraea Apaporiensis & 194135 & 1 & 3 & Stem bark & $\begin{array}{l}\text { Reed or } \\
\text { Liana }\end{array}$ & Native & Wild & $\begin{array}{l}\text { Not } \\
\text { reported. }\end{array}$ \\
\hline
\end{tabular}


Table Continued.

\begin{tabular}{|c|c|c|c|c|c|c|c|c|}
\hline Family & Species & $\begin{array}{l}\text { Numbers } \\
\text { of } \\
\text { voucher } \\
\text { specimen }\end{array}$ & $\begin{array}{l}\text { Number } \\
\text { of } \\
\text { Citations }\end{array}$ & $\begin{array}{l}\text { FI } \\
\text { (\%) }\end{array}$ & $\begin{array}{l}\text { Parte } \\
\text { used }\end{array}$ & $\begin{array}{l}\text { Plant } \\
\text { Type }\end{array}$ & Origen & $\begin{array}{l}\text { Cultural } \\
\text { State }\end{array}$ \\
\hline
\end{tabular}

\begin{tabular}{|c|c|c|c|c|c|c|c|c|c|}
\hline Meliaceae & $\begin{array}{l}\text { Guarea guidonia } \\
\text { (L.) Sleumer }\end{array}$ & 194112 & 1 & 3 & Stem bark & Tree & Native & Wild & $\begin{array}{l}\text { To soo the } \\
\text { stomach } \\
\text { pains, } \\
\text { diarrhea and } \\
\text { as a purgative }\end{array}$ \\
\hline
\end{tabular}

Menispermaceae

Abuta grandifolia (Mart.) Sandwith

194130

Abuta rufescens

Aubl.

194121

3

Sap

Reed or

Native

Wild

To cure fever and treat

headache and rheumatism.

To treat diarrhea and common illnesses (e.g. vomiting, headache, fever).

As a purgative and to soothe stomach pains.

Treats other diseases which manifest fever and headache.

Native

Wild 
Table Continued.

\begin{tabular}{|c|c|c|c|c|c|c|c|c|}
\hline Family & Species & $\begin{array}{l}\text { Numbers } \\
\text { of } \\
\text { voucher } \\
\text { specimen }\end{array}$ & $\begin{array}{l}\text { Number } \\
\text { of } \\
\text { Citations }\end{array}$ & $\begin{array}{l}\text { FI } \\
\text { (\%) }\end{array}$ & $\begin{array}{l}\text { Parte } \\
\text { used }\end{array}$ & $\begin{array}{l}\text { Plant } \\
\text { Type }\end{array}$ & Origen & $\begin{array}{l}\text { Cultural } \\
\text { State }\end{array}$ \\
\hline
\end{tabular}

\begin{tabular}{|c|c|c|c|c|c|c|c|c|}
\hline Myristicaceae & $\begin{array}{l}\text { Virola decorticans } \\
\text { Ducke }\end{array}$ & 194117 & I & 3 & Stem bark & Tree & Native & Wild \\
\hline
\end{tabular}

Plinia cf. duplipilosa McVaugh

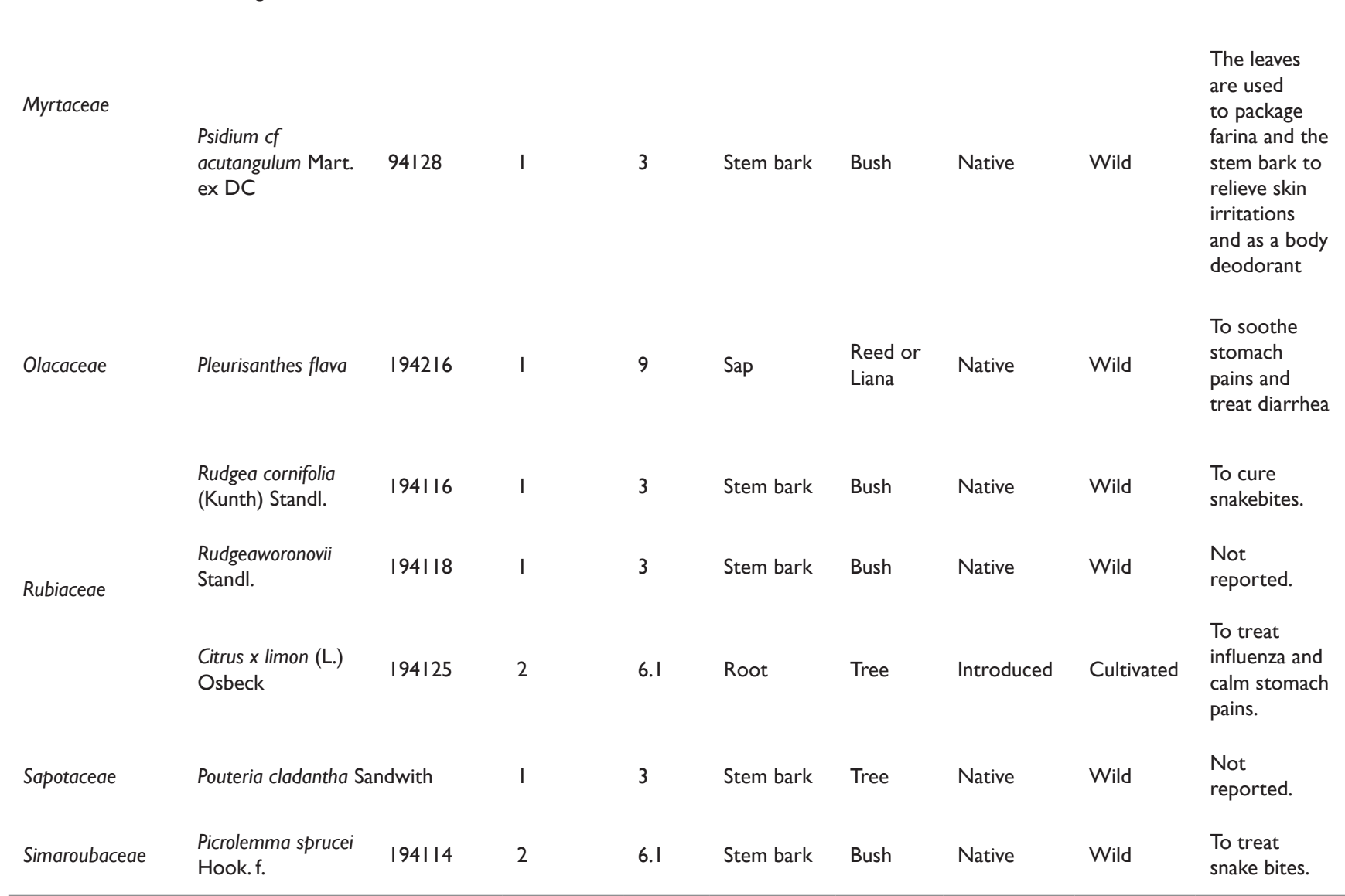

\section{Botanical and ethnobotanical findings for species whi- ch had no prior report of their antimalarialactivity}

1. Clathrotropis macrocarpa, is known in the region with the vernacular name, Tepaku. Tepa is the common name and $k u$ describes the male gender of the tree in the native Cubeo language. In the forest the plant can be identified by its big hand-shaped leaves and the strong odor of its yellow bark. The part of the tree used for treating malaria is the fresh stem bark. The extraction of the bark can be performed either when the tree is young or old. The bark is treated by decoction and it can be handled by both men and women. The medicine is either administered orally (for vomiting) or in baths to prevent the disease. It is advisable to administer the medicine orally only when the first symptoms arise, otherwise it could worsen the patient's condition in an advanced stage of the disease. It is contraindicated during pregnancy.

Medicinal use in the Amazon: In the northern part of the Colombian Amazon region, the leaf of the tree is used as afungicide and antibacterial. ${ }^{31}$ The species C. glaucophylla and C. macrocarpa have an economic relevance for the Yanomami people in Venezuela. They use seedsfrom the plant as food and the bark as an ingredient in the poison (curare) they apply to their hunting arrows. $^{32}$

2. Cosmos caudatus, is known in the region with the vernacular name of Abuju temuyo. Abuju is related to the devil, and temuyo means arrow. This plant is a weed that grows around the dwelling. It can be recognized by its aromatic smell, its saw-like leaves and its yellow flowers. The plant is a type of herb that grows wild, 
it is extracted during the young stage and collected in the adult stage. It can be handled by both men and women. The medicine can be administered orally and in baths. When the treatment is oral it consist ofa beverage of mashed leaves. The bath is used for preventing the disease and is prepared by mashing the whole plant and decoction.

Medicinal uses in different regions of the country: The Cuna people, in the Chocó region use the plant for body aroma and refreshment. They submerge the plant in cold water and use the liquid two times a day for bathing. 33 The Tukuna people in the Colombian Amazon region use the mashed leaves of Cosmos $\mathrm{cf}$. caudatusas a pain reducer for skin cuts and wounds. ${ }^{34}$

3. Matisia cf. glandifera, is known in the region with the vernacular names Vakoku, Eobukuiedo-umuijiku, Karuku Boriku, and Maka vakoku. Among the Cubeo people Vako is a kind of wild fruit similar to cocoaand ku means the male gender of the tree. Eo means belonging to a group of poisonous plants called barbascos, bukuiedo means old, and umujuijiku means tall tree. Karu is a tree known locally in Spanish as the "cargadero" (loader) and Bori means the color white. Maka means rain-forest or jungle. In the rain forest the species can be identified by its leaves which are similar to those from the cocoa plant, for its easily removable stem bark, and its characteristic smell. It is a species of native tree that grows wild. The parts of the tree used for treating malaria are the stem bark, the roots and the leaves in their fresh stage. These parts can be removed from both the young and mature tree. The medicine is prepared by decoction and it is safely handled by both men and women. The medicine can be administered orally and in baths. The baths are used for preventing the disease. Taken orally, the medicine is an emetic and is used to treat the disease. This rout is not recommended for those with an advanced stage of the illness because vomiting could worsen the condition. The medicine is recommended when the first symptoms of the disease appear. It is contraindicated during pregnancy. Medicinal uses in the Amazon: This species has no previous report, however one species from the same genre, Matisia cordata Humboldt et Bonpland, is used in the Amazon by the Tikuna people for menstrual problems. ${ }^{35}$ Also, the plant is used in Ecuadorian traditional medicine for treating Leishmaniosis. ${ }^{36}$

4. Monopteryx иacu, is a tree known in the region with the vernacular name of Avina given by the Cubeo people. The plant is a species of tree that grows wild in the studied region. The part of the tree used for treating malaria is the fresh stem bark removed from the adult tree. The medicine is prepared by decoction and it can be safely handled by both men and women. The medicine is administered orally and it has no contraindications.

Medicinal uses in the Amazon: no records were found.

5. Myroxylon balsamum, is a tree known in the region with the vernacular name of balsam. The speciescan be identified in the rain forest for its big leaves organized in sets of three and for the white underside of the leaves. The balsam tree grows wild in the studied region. The part of the tree used for treating malaria is the fresh stem bark removed from the adult tree. The medicine is prepared by decoction and safely handled by both men and women. The medicine is administered orally and it has no contraindications.

Medicinal uses in the Amazon: The plant is an effective medicine against respiratory illnesses such as rhinitis, chronic colds, bron- chitis, laryngitis, and tuberculosis. ${ }^{37}$ It is also used as an antiseptic for treating venereal diseases, against cholera, to heal peptic ulcers, for edemas, for healing scars and skin illnesses (e.g. nipple scars and perniosis), for dysmenorrhea, and for amenorrhea. It is also used as a stimulant. The "black balsam", as it is known in some places, has shown effective results for treating simple ulcers and those derived from syphilis, and for some cases of preeclampsia. ${ }^{38}$ Its resin is used as an expectorant, asthma reliever, cough suppressant and also to treat rheumatism. ${ }^{39}$

6. Plenotoma jasminifolia, it is known in the region with the vernacular names of Piararuamu (Cubeo language) and Juakekoda (Desano language). In the Cubeo language the word Piararua is a yanave or tucandira, a type of ant, and mu means vine. In the Desano language juake means fever and koda means remedy. It can be identified in the rain-forest because it is found in areas affected by human activity, such as farming. Its stems have a quadrangular shape with many small leaves and yellow flowers. It is a native vine that grows wild in the studied zone. The parts of the adult plant used for treating malaria are the stem bark, the root and in some cases, the whole vine is used when fresh. The preparation of the medicine is by decoction and the plant can be handled by both men and women. The medicine is administered orally for vomiting and as a beverage.It is contraindicated during pregnancy.

Medicinal uses in the Amazon: The smashed root is used for vomiting by the Huitoto indigenous community in Caquetá, Colombia as a remedy for bile disorders. ${ }^{37}$ The Miraña indigenous people of Caquetá use the plant for liver cleansing. ${ }^{37,40}$

7. Byrsonima japurensis, is known in the región with the vernacular name of Moari. In Cubeo language moa is related to fish, and ri is related to fish food. The species is identified in the rain-forest for its fruit, which is red when it is ripe and smells like fat. Also its leaves, when they are young, are red. The plant is a native tree that grows wild in the studied region. The part of the adult plant used for treating malaria is the fresh stem bark. The remedy is prepared by decoction and it can be handled by both men and women. The remedy is administered orally and it has no contraindications.

Medicinal uses in the Amazon: The Makuna indigenous people from the state of Vaupés, Colombia drink a tea using the leaves from this plant as a strong vermifugal agent. ${ }^{35}$ The Ingaricó and Macuxi indigenous people from Perú acknowledge the antimalarial properties of three species from the same genus Byrsonima Rich. Ex Kunth ${ }^{41}$ Another species of the genus B. crassifolia (L.) HBK, is reported as a good astringent and antipyretic. ${ }^{37}$

8. Hiraea Apaporiensis, belongs to a group of native tropical plants known as "bejucos" which have long, thin, flexible stems sometimes used to make fabrics and wicker furniture. It grows wild in the studied region. The part of the adult plant used for treating malaria is the fresh stem bark. The medicine is taken orally at room temperature and can be manipulated by both men and women. It has no contraindications.Medicinal uses in the Amazon: not reported.

9. Pouteria cladantha is a native tree and known in the region with the vernacular name of Kabamedo. In the Cubeo language kamabe means cane and do means tree. The parts of the plant used for treating malaria are the fresh stem bark and the fresh root. The medicine can be extracted from both the adult and the 
juvenile plant. The medicine is prepared by decoction and it can be handled by both men and women. It is administered orally and has no contraindications.

10. Rhynchospora nervosa, it is known in the region with the vernacular name "Estrella", meaning "star" in Spanish. It is a kind of native herb that grows wild. The whole adult plant is macerated and then used in a decoction for treating malaria. It can be handled by both men and women. The medicine can be taken orally or used in baths.

Medicinal uses in the Amazon: In the Villa Cachoeira communities (Ilhéus, Baíia, Brazil) the speciesis used as an anti-inflammatory medicine. ${ }^{42}$

11. Rudgea woronovii, it is known among the Desano people as Juako. Jua means fever and ko means, water, remedy or healing process. The species is a bush that when young, possesses big leaves with a purple underside. This native bush grows wild in the studied region. The part of the plant used for treating malaria is the fresh stem bark. The remedy is prepared by decoction and can be extracted when the plant is young or adult. It can be handled by both men and women. It is administered orally, and in small doses to children.

Medicinal uses in the Amazon: The leaves of an Amazon species of Rudgea can be cooked together with the crushed Persea gratissima seeds and Brownea wood, to prepare a contraceptive medicine, stopping the menstrual cycle for three to six months. ${ }^{35}$ The Chayahuita people in Peru use the leaves and the bark of $R$. loretensis Standl. to treat leishmanias is. ${ }^{43}$

12. Virola decorticans is known in the region with the vernacular name of Eobukue Bijoiku. In the Cubeo language Eo means barbasco, bukue means old, Bijo $i$ means to vomit, and $k u$ describes the male gender or means tree. The species is recognized in the field because it gives off a red latex and contact with the hairy leaves and branches causes itchy skin. It is a native tree that grows wild in the study region. The part used for treating malaria is the fresh stem bark. The remedy is extracted by decoction from the juvenile plant, and can be handled by both men and woman. It is administered orally and contraindicated during pregnancy.

Medicinal uses in the Amazon: The Maiongong people cook the leaves and bark of a species of this genus to prepare baths for the treatment of malaria. ${ }^{41}$ Other species of the genus $V$. callophylla Warb. in Brazil (Prance 1972) and V. carinata (Benth.) Warb among the Taiwanos people in the Colombian Amazon, are used as antimalarials. ${ }^{35}$

13. Plinia cf. duplipilosa, is known in the region by the Carapana people as Makanuku uku. Maka means mountain, nuku refers to the section or islet where the plant is found, and ukumeans tree. The species is recognized in the field due to its similarity to the guava plant. The species is a native tree that grows wild in the studied region. The part of the tree used for treating malaria is the fresh stem bark. The remedy is extracted by decoction from both juvenile and adult stem bark. It can be handled by both men and woman. It is administered orally and is contraindicated in children.

Medicinal uses in the Amazon: No reports were found.

14. Psidium acutangulum is known in the region by the Cubeo people as Nujoku. Nujo is an Amazonian fish and ku means tree. It is recognized by its fruit that is similar to the guava fruit. The plant is a native shrub that grows wild on the banks of the river. The part used for treating malaria is the fresh stem bark extracted from the adult tree. The remedy is prepared by decoction and can be handled by both men and woman. It is used as an emetic and is contraindicated during pregnancy and in patients with an advanced stage of malaria.

15. Rudgea cornifolia is known in the region with the vernacular name Adapedikoku. In the Cubeo language, Ada is snake or serpent and pedikoku is attributed to a tool used to scratch the bitter cassava, locally known as "rayo" or shaft. The species is recognized in the field by its leaves that break easily and by its white flowers. The plant is a native shrub that grows wild. The parts used for treating malaria are the fresh stem bark and fresh root taken from either the juvenile or adult plant. The remedy is extracted by decoction and can be handled by both men and women. It is administered orally and children should take only one tablespoon. The remedy is contraindicated during pregnancy.

Medicinal uses in the Amazon: The leaves of an Amazonian species of Rudgea are cooked with the crushed seeds of Gratissima Persea and Brownea wood to prepare a contraceptive drink that stops menstruation for three to six months. ${ }^{35}$ The Chayahuitas in Peru use the leaves and bark of $R$. loretensis Stand 1 to treat leishmaniasis. ${ }^{44}$

16. Pleonotoma variabilis is known in the region with the vernacular name Piararuamu. In the Cubeo language, piara is an ant that bites known locally as yanave or tucandira, and mu indicates a vine-like plant known as a bejuco. The plant can be identified in the region by its quadrangular stems and three large leaves. The plant is a native vine that grows wild. The part used for treating malaria is the fresh stem bark. The remedy is extracted from the adult plant by decoction and can be handled by both men and woman. It is administered orally.

Medicinal uses in the Amazon: The Miraña people use P. variabilis to treat blindness. ${ }^{40}$

17. Clytostoma binatum is known in the region with the vernacular name gapui. It is a native vine that grows wild. The fresh root taken from the adult plant is used to prepare the malaria treatment. The remedy is extracted by decoction and can be handled by men and women. It is administered orally and no warnings were reported.

\section{Medicinal uses in the Amazon: No reports were found}

18. Arrabidaea verrucosa is known in the region with the vernacular name Yuparimu Yoka Uraku (Cubeo). Yupari refers to an Amazonian fish with white scales and a red tail known locally as "colirrojo", mu means vine, yoka means leaf, ura means large and $\mathrm{ku}$ refers to the male gender or tree. The species is recognized in the field because it is a very strong vine, has small red flowers and round leaves that are arranged in pairs. It is a native vine that grows wild. The part used for treating malaria is the fresh stem bark which can be removed from both juvenile and adult plants. The remedy is prepared by decoction and can be handled by both men and women. It is given orally. The traditional healer warns that this remedy should not be combined with other medications.

Medicinal uses in the Amazon: The inhabitants of Jau National Park located in the Amazonas state reported this species for treating gastrointestinal disorders. ${ }^{45}$ 
19. Callichlamys latifolia is known in the region with the vernacular name Miyavikubobaku (Cubeo). Miyavi is eagle, kuboba means leg or foot, ku refers to the male gender or tree. The species is recognized in the field mainly by its leaves which are arranged in threes and resemble a hawk's claw. It is a native vine that grows wild. An extraction of the fresh root is prepared for the treatment of malaria. The extraction can be prepared by decoction of the fresh root from either the juvenile or adult plant and can be handled by both men and women. It is administered orally, is contraindicated during pregnancy and cannot be combined with other drugs.

Medicinal uses in the Amazon: In the Peruvian Amazon (Valley Chazuta) it is used against eye irritation, ${ }^{46}$ in the Oyapock basin (French Guyana) it is used for the treatment of leishmaniasis. ${ }^{44}$

20. Senna spinescens is known in the region with the vernacular name Yuparimu Yoka Kijiku (Cubeo). Yupari in Cubeo refers to an Amazonian fish with white scales and a red tail known locally as "colirojo", mu means vine, yoka means leaf, kijiku means small and ku refers to the male gender or tree. The species is recognized in the field by its texture and its similarity to a cultivated plant known as guamo (species Inga). It is a native tree that grows wild on the slopes of the rivers. The part used for the treatment of malaria is the fresh stem bark. The remedy can be extracted from both juvenile and adult trees, is prepared by decoction, and can be handled by both men and women. It is administered orally.

Medicinal uses in the Amazon: The Kofanes consider the leaf dust of the S. spinescens as an excellent repellent for body lice. ${ }^{35}$ The species of a genus very near to Senna are reported as medicinal in the Northwest Amazon by Schultes et al. ${ }^{35}$

21. Anaueria brasiliensis is known in the region with the vernacular names Yurajiku (Cubeo) or Aguacatillo (mestizo). The species is recognized in the field by its leaves and fruit which resemble the avocado plant (Persea americana), its red stems and yellow flowers. It is a native tree that grows wild in both mature and managed forests. The part used for treating malaria is the stem bark. The remedy can be extracted from both juvenile and adult trees by decoction and can be handled by both men and women. It is administered orally.

Medicinal uses in the Amazon: there are no references that indicate that the species is used as a medicinal plant. However, it is used for timber. ${ }^{47}$

22. Inga umbellifera is known in the region with the vernacular name, Bubumeneku (Cubeo). Bubu is an anuran locally known as toad, mene refers to a fruit in the form of a legume or pod, known locally as guama and ku describes the male gender or tree. The species is recognized in the field by the arrangement of its leaves, the red stem bark and the small bright green fruits shaped like legumes, known locally as "guamas pequeñas". It is a native tree that grows wild in mature forests or jungle. The part used for the treatment of malaria is the fresh stem bark. The remedy can be extracted from both juvenile and adult trees, is prepared by decoction, and can be handled by both men and women. It is administered orally. In the region no adverse or toxic effects of this plant were reported.

Medicinal uses in the Amazon: Other species of the genus have been reported for antimalarial use: Inga acreana Harms by the inhabitants of Loja and Zamora-Chinchip. ${ }^{48}$ Inga sessilis Mart. is used in Brazil and Inga sertulifera DC. is employed by the
Achuales in Peru. ${ }^{41}$

23. Tovomita $s p$. is known in the region with the vernacular name Jiadavipicomu (Cubeo). Jiadavi is a species of carnivorous mammal that lives mainly in the Amazon, also known as giant nutria, water wolf or water dog and picomu means tail. The species is recognized in the field by its long, thick and rough leaves, and also for its quadrangular stems which resemblean otter's tail on young stems. It is a native shrub that grows wild. The treatment for malaria is extracted from the fresh root bark from juvenile shrubs. It is prepared by decoction and can be handled by both men and women. It is administered orally and no adverse or toxic effects of this plant were reported in the region.

Medicinal uses in the Amazon: In Peru, the Tovomita stylosa and Tovomita foldatsi species are reported as anti-inflammatory agents and as antimicrobials. Also in Peru, another Tovomita species was reported in a study investigating its antileishmaniasis and antimalarial properties.46 In the Peruvian Valley of Chuzuta, T. carinata in decoction, is used against rheumatism. ${ }^{49}$

24. Machaerium $s p$. is known in the region with the vernacular name Abujuku Muimu Yoka Kijiku (Cubeo) or stairs of the devil small leaves. Abuju refers to the devil, ku means the male gender or tree, mui means going up, mu refers to a vine, and kijiku indicates small. This vine is recognized in the field because it is indented and a red color latex is released after cutting it. It is a native vine that grows wild. Fresh sap is used for the treatment of malaria and when not available, the adult stem bark is used to prepare an extracted by decoction. It can be handled by both men and women. It is administered orally and no adverse or toxic effects of this plant were reported in the region.

Medicinal uses in the Amazon: In Peru, the M. floribundum species is reported as antidiarrheal and used against sexual impotence (Rengifo 2001).

25. Cissampelos $S p$. is known in the region with the vernacular name Muñumu (Cubeo). In Cubeo, muñu refers to the piranha, locally known as "fist" or "Caribbean" and mu means vine. It is cultivated, therefore it is easy to recognize. It is a native vine. The treatment for malaria is extracted from the adult stem or vine by decoction and can be handled by both men and women. It is administered orally and is contraindicated during pregnancy.

Medicinal uses in the Amazon: The Peruvian Yanesha ethnic group (Amuesha), squeezes and makes juice from the $C$. andromorpha species and administers it via the ocular rout to soothe headache and nausea ${ }^{50}$ In northeastern Brazil the species C. sympodialis is used to treat fever, influenza, asthma and lung infection. $^{51}$

26. Pleurisanthes flava. is known in the region with the vernacular name Kuramu (Cubeo). Kura means stone and mu means vine. This vine is known in the field as being resistant. When struck with a machete, the resulting sound is similar to striking stone or iron. The leaves are white on the underside. It is a native vine that grows wild. The part used for the treatment of malaria is the fresh sap, extracted in adulthood. It can be handled by men and women. It is administered orally and has no adverse or toxic effects reported in the region.

Medicinal uses in the Amazon: In Peru the species H. acuminata is reported as antimicrobial and is used during the shamanic initiation processes. ${ }^{52}$ In Ecuador the same species is reported with anti-inflammatory and antioxidant properties. ${ }^{53}$ 
27. Euterpe $S p$. is known in the region with the vernacular names emimoeñu (Cubeo) or wipiño (Desano). The species is recognized in the field as a palm with long divided leaves. This palm tree grows wild in the studied region. An extract of the fresh root from either the juvenile or adult plant is used to treat malaria. It is prepared by decoction and can be handled by men and women. It is administered orally and this plant has no reported adverse or toxic effects in the region.

Medicinal uses in the Amazon: A preparation of the root from the Euterpe precatoria species in the French Guyana, Bolivia and Peru has antimalarial use.54-56 Moderate antiplasmodial activity has been reported with this species. ${ }^{57,58}$ Euterpe oleracea combined with Carica papaya, Citrus sp. (Lemon), and Quassia amara, is used as an antimalarial in French Guyana..$^{59}$ Euterpe oleracea has also demonstrated antioxidant activity, ${ }^{60}$ and is used by the French Guyana indigenous Oyapock group to cure Leishmaniasis. ${ }^{44}$

28. Fabaceae could be identified only to the family. It is known in the region as Pagapunisuore (Desano). This shrub is recognized in the field by its long petiole and for the ferruginous underside of the leaf. It is a native shrub that grows wild in the studied region. The fresh root is used for the treatment of malaria. The treatment is extracted by decoction and then combined with the sap of Doliocarpus dentatus (related to Heisteria $s p$ ). Itis administered orally and can be handled by both men andwomen. This plant has no reported adverse or toxic effects in the region.

Other uses reported by the traditional healers: Used to calm headache, fever and stomach pain.

Following, is a more detailed description of the 14 species reported both here in this study and previously in the literature for their antimalarial use.

I. Abuta grandifolia is a native bush that grows wild in the study area. An extract of a mixture of root and stem bark are prepared by decoction and used for the treatment of malaria. In our study this species was reported by 9 traditional healers, yielding a FIof $27.2 \%$, the species with the highest value. The revised herbarium labels contained the following reports for uses of $A$. grandifolia: the preparation of a poison applied to arrows for hunting known as "curare" (García-Barriga ${ }^{37} 14371, \mathrm{COAH}$; Gutiérrez 01, COAH; Pabón A ${ }^{29} 620 \mathrm{COAH}$; La Rotta 35 COL; La Rotta ${ }^{39} 160$ COAH; Pabón A. ${ }^{30} 621$ COL; Pabón E ${ }^{30} 704$ COAH, COL; Torres Duque $1094 \mathrm{COAH})$, preparing poison for blowguns used in hunting (Balcázar, Castroy Suárez 584 COAH, $\mathrm{COL}$ ), for wound healing (López et al. $6002 \mathrm{COAH}$ ), to treat anemia (Arias-G. et al. $1165 \mathrm{COAH}$ ), for inducing abortion (Gaitán et al. $13 \mathrm{COAH}$ ), for the treatment of malaria (Arias-G. et al 1165 COAH; Correa et al. 2756 COAH; Collazos y Narváez 46 COAH; Gaitán et al. 13 COAH; Gaitán et al. 88 COAH; La Rotta 035 COAH; López et al. 6002 COAH; Caicedo y Oidor 1758 COAH, COL; Pabón E. 1013COAH) and for alleviating symptoms associated with malaria (Correa et al. ${ }^{16} 2756 \mathrm{COAH}$; Gaitán et al. 88COAH; Pabón E. $621 \mathrm{COL})$. Furthermore, secondary metabolites and purified extracts from species of the genus Abuta (Menispermaceae) found in the Amazon, have presented effective antiplasmodial activity. ${ }^{61}$ Steele et al. isolated three bisbenzylisoquinoline alkaloids from the bark of $A$. grandifolia, of which kukrovine and limacine showed the highest antiplasmodial activity against $P$. falciparum. ${ }^{62}$ Garavito et al.${ }^{63}$ found that the crude alkaloid extract from the leaves of this species presented in vitro activity against the $P$. falciparum strain FcB2 10 times greater than that obtained from the Remijia peruviana species (control species with quinones). Additionally, in vivo studies using mice infected with $P$. berghei, the same extract at a concentration of $250 \mathrm{mg} / \mathrm{kg}$, inhibited parasite growth by $66 \%$ without evidence of cytotoxicity. ${ }^{63}$

II. Aspidosperma excelsum is a native tree that grows wild in the study area. An extract of the stem bark is prepared by decoction and used for the treatment of malaria. Extracts and secondary metabolites purified from Amazonian plants of the genus Aspidosperma (Apocynaceae) have shown effective antiplasmodial activity.61 No information was found on the herbarium labels for the A. excelsum species, however, others have reported its antimalarial use. Rodrigues reported that the inhabitants of the Jaú National Park in the Brazilian Amazon, used the bark of this plant for the treatment of malaria. ${ }^{45} \mathrm{Kvist}$ et $\mathrm{al}{ }^{64}$ reported the antimalarial use of $A$. excelsum among the inhabitants of eleven geographic and ethnic areas of Loreto in the Peruvian Amazon. They also reported an average antiplasmodial activity $\left(\mathrm{CI}_{50}\right)$ between $10-50 \mathrm{mg} / \mathrm{mL}$. ${ }^{64}$ The Ingaricó indigenous people and local communities in the states of Roraima and Para, Brazil, used the bark in a bitter decoction or infusion for the treatment of malaria. ${ }^{41,65}$

III. Mangifera indica is an introduced a tree grown in the study area. For the treatment of malaria the stem bark prepared by decoction is used. On the revised herbarium labels, reports were found indicating that the fruit of M. indica is edible (Diaz J., et al. 151 COAH. Blair et al. (2005) reported this species with antimalarial use and for tonsillitis in a study conducted near the Colombian Pacific. In an ethnobotanical study on malaria conducted in the Budiope County, Uganda, $M$. indicawas one of the species most often cited. ${ }^{66}$ In similar studies conducted in the Dangme district of West Ghana, ${ }^{67}$ in Nigeria ${ }^{68}$ in an area southwest of Nigeria, ${ }^{69}$ and in the maritime region of Togo, ${ }^{70}$ all found M. indica was used to treat malaria. The Tikunas of the River Loretoyacu consider the decoction of the leaves as a contraceptive. ${ }^{35}$ Awe et al. ${ }^{71}$ reported that the methanolic extract from the bark of $M$. indica presented antiplasmodial activity against Plasmodium yoelii nigeriensis schizonts in the early stages of infection. In addition, it reduced yeast induced hyperpyrexia in rats. According to the authors, these effects can explain the use of the plant in traditional medicine to treat malaria and fever Valadeau et al. ${ }^{49}$ tested in vitro antimalarial activity of 14 plant species, including $M$. indica, which was marginally active compared to the others. The leaves and bark of $M$. indica have a low toxicity with an $\mathrm{LC}_{50}$ of $3079.1 \mu \mathrm{g} / \mathrm{mL}$ and $2456.0 \mathrm{mg} / \mathrm{mL}$ respectively. ${ }^{72}$

$I V$. Matisia glandifera is a native tree species that grows wild in the study area. The stem bark and leaves are used for the treatment of malaria. The treatment is prepared by decoction. This species was reported by four traditional healers giving it a FI of $16 \%$. Other uses reported by the traditional healers: To relieve headache and bone pain and as a fever reducer. For the species $M$. glandifera, no records of medicinal uses were found on the labels from the three herbariums used. On the other hand, one study reported that this plant is used to treat malaria and leishmaniasis in Loreto, Peru. ${ }^{64}$ A species of the same genus M. cordata Bonpl., is used in the Amazon by the Tikuna people to treat "menstrual problems". ${ }^{35}$ This species is used in Ecuadorian traditional medicine for the treatment Leishmaniasis. ${ }^{36}$

V. Guarea Guidonia is a native tree that grows wild in the study area. The part used for treating malaria is the stem bark, which is prepared by cooking. On the revised herbarium labels for $\mathrm{G}$. 
Guidonia, usage reports were found on two labels. The bark is scraped, placed in water and used as a purgativefor humans (Marín et al. 2386, COAH) and for dogs (Little Jr. 7469, COAH) The bark is also used for the treatment of malaria (Córdoba et al. 393, COAH). One report found that the aerial plant organs have antiplasmodial activity in vitro. ${ }^{73}$ The dichloromethane extract from the seeds demonstrated good antimalarial activity $\left(\mathrm{IC}_{50} \geq 10 \mu \mathrm{g} / \mathrm{mL}\right)$ in the F32 and D2 P. falciparum strains susceptible to chloroquine and D2 strains resistant to chloroquine. The cytotoxicity was $28.8 \pm 8.2 \mathrm{ug} / \mathrm{mL}$ in the U-937 cell strains. ${ }^{74}$ The crude plant extract has anti-inflammatory activity. ${ }^{75}$ Sesquiterpenes, ${ }^{76}$ terpenes, diterpenes, steroids ${ }^{77}$ and pregnane have all been isolated from an ethanol extract from the leaves. ${ }^{78}$

VI. Picrolemma sprucei is a native shrub that grows wild in the study area. The stem bark is used for the treatment of malaria, which is prepared by decoction. The herbarium labels contained information on various medicinal uses for this species. It is used to treat sores (Pabón E. 513, COAH, HUA), to treat skin fungus and insect bites (Garzón, Mendoza and Rivera 230, COAH), in the preparation of ichthyotoxins (La Rotta40 $128 \mathrm{COAH}$ ), and to eliminate the "chunche" (La Rotta40 170, COAH; Pabón E. 613, COAH). In Brazil, French Guyana and Peru this plant is used for the treatment of malaria.79 The family to which this species belongs, Simaroubaceae, contain quassinoids responsible for the anti-malaria, anti-cancer and antiamoebic activity. 38 The cuasinoide neosergeolide was isolated from the stem and root of this species, which has significant in vitro activity in multidrug resistant $\mathrm{P}$. falciparum, being more active than quinone and chloroquine ${ }^{80}$ This cuasinoide together with another called isobrucein $\mathrm{B}$, showed cytotoxicity against tumor cells in humans and worked as a larvicide against the A. aegypti mosquito responsible for the spread of dengue. Further, the lack of hemolytic activity in vitro could indicate specificity of the cytotoxic effects observed ${ }^{81}$

VII.Potalia resinifera is a native shrub that grows wild in the study area. The stem bark is used to treat malaria, and the treatment is prepared by decoction. In pharmacological terms, Potalia is the most important genre of the Gentianaceae family in South America. The species of this genus are widely used by native peoples in South America for the preparation of remedies commonly used for fevers, snakebites and inflammation. ${ }^{82}$ In Colombia, the indigenous Barasana group of the Vaupés used the plant to treat eye inflammations and in Córdoba it is used in Shamanism. In Peru, the root is used to kill parasites. The root and resin are used in the province of Pasco for the treatment of rheumatism and anemia. The leaves are rubbed on the back to relieve pain and baths are made with the infusion of the plant to calm crying babies. In Ecuador, cooked and shredded leaves are used in the province of Napo to treat skin problems. There is a possibility that there are more uses reported for this species, since in some herbariums the specimens of $P$. resinifera have been named $P$. amara, determined by applying a sensu lato taxonomic criterion for the latter. ${ }^{82}$

VIII. Abarema laeta is a native tree that grows wild in the study area. An extraction of the stem bark is prepared by decoction and used used for treating malaria. In the Peruvian Amazon, A. laeta is used to treat malaria. ${ }^{41,83,84}$ The species was reported as malarial by the Quechua indigenous group and by the Mestizos of Loreto (Peru), however no antiplasmodial activity was found. ${ }^{84}$
The Achual natives of Perú use the bark in an infusion to treat malaria. ${ }^{41}$

IX. Jacaranda copaia is native tree that grows wild in the study area. The cooked bark is used for malaria treatment. From the herbarium labels the following uses are reported: the young leaves (called "cogollo" or tender hearts) are pulverized and used to heal skin infections (La Rotta and Martinez 695, COL) and to treat skin ulcers. ${ }^{36}$ The leaf is macerated, cooked in water to a honey-like consistency and the decoction is used to: heal skin lesions (Rotta 90, COAH); for bone pain, to attenuate forunculosis, treat venereal diseases, for cystitis and neuralgia. ${ }^{36}$ The juice extracted from the macerated root is used to treat blindness (Pabón E. 548, COAH). The Yanesha (Peru) use boiled leaves of $J$. copaia, to cure malaria and for cutaneous leishmaniasis. In mild cases of leishmaniasis, the remedy is applied to the affected areas as a cataplasm (Céline et al. 2009). The plant is used to heal wounds by the Andoques and to treat blindness by the Huitotos. ${ }^{85}$ The indigenous people of the Vaupes River scrape off the bark and prepare an infusion for the treatment of influenza and pneumonia. ${ }^{35}$

X. Tabebuia serratifolia is a native tree that grows wild in the study area. The cooked stem bark is used for treating malaria. The bark is used by the Wayãpi natives in the French Guyana, as a fever reducer. ${ }^{83}$ The species contains alkaloids, lapachol or tacomine, catechins, steroids, simple phenols, flavonols, flavones, flavanones, cyanogenic glycosides, resins, saponins, triterpenes and xanthones. ${ }^{86}$

$X I$. Crescentia cujete is a tree introduced and grown in the study area. The cooked stem bark is used for malaria treatment. Three reports for medicinal uses of $C$. cujete in the herbarium specimens were found. It is used for reperatory problems (Cárdenas et al. 13849, COAH). The leaf is used in a poultice for headaches and the young fruit is used to prepare "melao" used as a cough suppressant (Cardenas and Romero 13226, COAH). The endocarp is cooked with "panela" or brown sugar and used to reduce inflammation resulting from hits or blows to the body (Marín et al. 2336, COAH). Ruiz et al. ${ }^{56}$ report that $C$. cujete leaves are used as an antimalarial. ${ }^{56}$ The Chami natives (Risaralda, Colombia) use the unripe pulp to treat diarrhea ${ }^{87}$ Mature pulp is employed to calm headaches, is cooked in a sweet broth and used as a febrifuge, purgative and expectorant, and the leaves applied on the belly facilitate parturition. ${ }^{38}$ In Latin America, the fruit pulp is used for respiratory diseases, ${ }^{87}$ gastrointestinal illnesses, inflammation and urethritis. ${ }^{89-91}$ Decoction of the leaves and flowers is used in vaginal baths for leucorrea, to treat earaches, treat skin conditions such as scrapes, bumps or dermatitis, is used to treat hemorrhoids, treat tumors, expel the placenta, against venoms, and as a homeostatic. ${ }^{92-94}$ The leaves are used to treat anemia. ${ }^{38,95}$ In India, the fruit pulp is used as a diuretic. ${ }^{96}$ In Malaysia the leaves in infusion are used as a demulcent and antitussive, and the seeds administered orally are used as an anti venom. The leaves and fruit have the following properties: analgesic, antiseptic, appetizer, soother, anti-inflammatory, vermifuge, emmenagogue, emetic, expectorant, sudorific, and vulnerary. ${ }^{38}$

XII. Doliocarpus dentatus is a native vine that grows wild in the study area. The sap is used to treat malaria. The Kubeos indigenous group on the Kuduyari River consider the "water" from $D$. dentatus stops the effects of malaria. ${ }^{35}$ The Popoluca and Mixe indigenous groups (Mexico) use the species for different medi- 
cinal purposes..$^{97}$ The Aguaruna community in northwest Peru, this lianais used to treat the sequelae of malaria. ${ }^{98}$

XIII. Abuta rufescens is a native vine that grows wild in the study area. The sap is used to treat malaria. Indigenous groups in the state of Roraima, Brazil, use A. rufescens to treat malaria. ${ }^{41}$ The Shipibo-Conibo people usethe leaf to prepare "curare" and a decoction of the bark to treat malaria, stomach ulcers, diabetes and liver pain. ${ }^{84}$

XIV. A.rufescens presented leishmanicidal activity. ${ }^{99}$ Extracts from the bark and leaves had antiplasmodial activity with $\mathrm{IC}_{50}$ from 2.3 to $7.9 \mathrm{ug} / \mathrm{mL} .{ }^{84}$ This species was found to contain the alkaloids $(+)$ - Aromaline, $(+)$ - Homoaromaline, Homomoschatoline, Imeluteine, Imenine, Imerubrine, Lysicamine, (-) -Krukovine, Nomifescine, Rufescine and Splendidine. ${ }^{100}$

XV. Citrus $x$ lemon, is a tree introduced and grown in the study area. An extract of the root is prepared by decoction and used for the treatment of malaria. Antimalarial use of Citrus $x$ lemon was reported in the Ucayali region of Peru. ${ }^{30}$

\section{Discussion}

In this study, most of the respondents are male. Men seem to possess more traditional knowledge of medicinal plants compared to women, possibly due to their increased access to the forest to hunt, collect wild fruits and plants, and obtain material for housing construction and development of tools. These activities allow them to acquire forest-related knowledge, while on the other hand, women are dedicated to the care of charges and care of the house. In the communities represented in this study, women have more access to plants grown in home gardens. The number of woman participants in this study is low because most plants used for malaria are found in the forest. This finding is consistent with research conducted by Boster ${ }^{101}$ and Garro ${ }^{102}$ who mentioned that the knowledge of any given person is determined by their role in society (gender, age, division of labor, individual experience), creating differences in access to knowledge.

The largest number of species reported, is observed in the community of Puerto Laguna. This result could be due to the presence of the only Paye who participated in the study. The Paye is the most influential community member who passes on their knowledge to the younger generations. Yurupari, is a community that also reported a large number of species. This could be due to their proximity to Puerto Laguna and the observed relationship between the inhabitants of these communities, allowing transmission of knowledge between traditional healers.

The families with more genera and species reported are Bignoniaceae ( 8 species/6 genera) and Fabaceae (4 species/4 genera). According to Gentry ${ }^{103}$ the Bignoniaceae family predominates among the plants with medicinal use. Gentry identified 27 genera of lianas and nine genera of trees, all with therapeutic properties. The finding in this study of several species belonging to the Bignoniaceae family with antimalarial use may be due to the wide geographic distribution of this family and the presence of secondary metabolites of naphthoquinone, such as lapachol. ${ }^{104}$ On the other hand, the Fabaceae family is also often used for medicinal purposes. According Leonti, this is probably due to its abundance and high diversity of active constituent chemicals with organoleptic properties ${ }^{97}$ Alkaloids, flavonoids and polyphenols have been isolated from this family. The activity of these metabolites is associated with antidiabetic ${ }^{106}$ anti-inflammatory ${ }^{106}$ and antimicrobial effects. ${ }^{107}$
The type of plant most reported by the traditional healers of the Vaupés medio was the tree, with 19 tree species reported. This can be easily explained due to the fact that most of the plants used to treat malaria were collected in mature forests or forests with little intervention, a pattern that has been observed in other studies. ${ }^{2}$ The species collected and identified are mostly native $(90.24 \%)$. This is evidence that the species indeed grow wild in the study area and demonstrates the persistence of indigenous knowledge using native vegetation, consistent with what was found by Perez in the Peruvian Amazon. The part of the plant reported with the highest frequency for its use in the production of anti-malarial remedies was the stem bark. This may be due to the preference of the traditional healers to remove a part of the organ without damaging the whole plant, "so that it does not dry up." Additionally, the traditional healers think that the substances responsible for the activity are concentrated in the bark and extraction of this part is simple. The leaves are used with a lower relative frequency compared to the other organs. It is noteworthy that the traditional healers do not use fruits for the treatment of malaria. This practice is possibly due to the fact that the fruits are not available permanently and malaria can occur at any moment.

Among the species collected in this study, only four usage records were significant (i.e. they had higher citation frequency in the interviews conducted in the ten communities visited). Never the less, only Abuta grandifolia, with an FI of 36\%, exceeded the $20 \%$ citation frequency. This is a strong indicator that this species deserves special attention for validation and scientific evaluation.

\section{Conclusion}

Based on the Friedman's consensus technique of informants, the species most reported as antimalarial by healers of the Middle Vaupes are: Abuta grandifolia, Aspidosperma excelsum, Matisia cf. glandifera and Pleonotoma jasminifolia. More studies are necessary to validate ethnobotany data. It is important to verify the efficiency of each plant to kill malaria parasites, especially giving special attention to the species Pleonotoma jasminifolia, which has no previous report in the literature as antimalarial. Through this work we were able to demonstrate that despite the social and cultural changes that lead to the rapid disappearance of ancestral knowledge, active traditional healers within the Colombian native communities still exists and hold an important place in society for the knowledge they possess.

As for the medicinal flora, important information was gathered revealing 42 species with antimalarial use in these 10 indigenous communities. This work can support further phytochemical investigations, especially for those plants with no bibliographic reports so far. In such a small area of the Amazon species with no previous report of antimalarial activity were discovered. For this reason it is necessary to conduct more ethnobotanical studies in the region.

\section{Authors Contributions}

OR contributed in collecting plant sample, SB contributed to design the study and critical reading of the manuscript, FC contributed in collecting plant sample and identification, confection of herbarium and morphological description of the species. AP designed the study, supervised the field work, and drafted the paper and contributed to critical reading of the manuscript. All the authors had read the final manuscript and approved the submission contributed to analysis of the data.

\section{Acknowledgments}

This project was funded by Colciencias grant 1115-489-25104 
RC 506-2009, Universidad de Antioquia, sustainability strategy 2014-2015. The authors would like to thank the Herbarium of the Universidad de Antioquia and Dr. Monserrat Rios who gave valuable advice over a 4 month period. The authors would also like to thank the traditional healers representing the 10 communities, for their trust and cooperation. Without their permission and cooperation this investigation would not be possible.

\section{Conflicts of interest}

The authors have no conflicts of interest.

\section{References}

1. WHO. World malaria report, World Health Organization, Geneva, Switzerland; 2015

2. Ladio A, Lozada M, Weigandt M. Comparison of traditional wild plant knowledge between aboriginal communities inhabiting arid and forest environments in Patagonia, Argentina. J Arid Environ. 2007;69(4):695-715.

3. INS. Instituto Nacional de Salud- Dirección de Vigilancia y Análisis del Riesgo en Salud Pública. Informe de Vigilancia y control, Colombia; 2016

4. Ta TH, Hisam S, Lanza M, J et al. First case of a naturally acquired human infection with Plasmodium cynomolgi. Malar J. 2014;13:68.

5. Kitua AY, HM Malebo. Malaria control in Africa and the role of traditional medicine. Traditional medicinal plants and malaria. 2004. p. $3-18$.

6. Campuzano-Zuluaga G, Alvarez-Sánchez G, Escobar-Gallo GE, et al. Design of malaria diagnostic criteria for the Sysmex XE-2100 hematology analyzer. Am J Trop Med Hyg. 2010;82(3):402-411.

7. Bermúdez A, Oliveira Miranda MA, Velázquez D. La investigación etnobotánica sobre plantas medicinales: una revisión de sus objetivos y enfoques actuales. Interciencia. 2005;30(8):453-459.

8. Rieckmann KH, Antuñano FJL. Chloroquine resistance of Plasmodium falciparum in Brazil detected by a simple in vitro method. Bull World Health Organ. 1971;45(2):157-167.

9. Tang W, Eisenbrand G. Chinese drugs of plant origin. Chemistry, pharmacology, and use in traditional and modern medicine. Springer-Verlag. 1992.

10. Hien TT, White NJ. Qinghaosu. The Lancet. 1993;341(8845):603-608.

11. Gentry AH. Tree species richness of upper Amazonian forests. Proc Natl Acad Sci USA. 1988;85(1):156-159.

12. Gari J. Biodiversity and indigenous agroecology in Amazonia: The indigenous people of Pastaza. Etnoecologica. 2001;5(7):21-37.

13. Guevara Garzón J. En busca de un modelo de salud para los pueblos indígenas. La experiencia del Vaupés. Mitú: Servicio Seccional de salud del Vaupés, Ministerio de salud. 1998.

14. Bodnar Y. Pueblos indígenas de Colombia: apuntes sobre la diversidad cultural y la información sociodemográfica disponible. afrodescendientes de América Latina y el Caribe: información sociodemográfica para politicas y programas. 2006. p. 135-154.

15. IGAC. Instituto Geográfico Agustín Codazzi. Diccionario geográfico de Colombia, Colombia; 1996.

16. Correa F. Elementos de identidad y organizacion social entre las comunidades indigenas de la region del Vaupés. Maguare Bogota. 1983;2(2):97-123.

17. Alexiades MN. Collecting ethnobotanical data: an introduction to basic concepts and techniques. Advances in Economic Botany. 1996;10:53-96.
18. Hammersley M, Atkinson P, Otazu MA. Etnografia: métodos de investigación. Paidós Barcelona, Spain; 1994.

19. Martin GJ. Ethnobotany: a methods manual. Earthscan/James \& James. 2004.

20. Taylor S, Bogdan R. Introducción a la observación participante. in cap 2. Paidós Barcelona, Spain; 1992.

21. Valles MS. Técnicas cualitativas de investigación social. Sintesis Editorial. 2000.

22. Hamme M, Atkinson P. Etnografía. Métodos de investigación. Barcelona, Paidós, México; 1994.

23. Hammersley M. Etnografía. In: Atkinson P, editor. Métodos de investigación. Paidós, México; 1983.

24. Goodman LA. Snowball sampling. The Annals of Mathematical Statistics. 1961;32(1):148-170.

25. Cunningham AB. Applied ethnobotany: people, wild plant use and conservation. Earthscan/James \& James, UK; 2001.

26. Cunningham AB. Etnobotánica aplicada. Pueblos, uso de plantas silvestres y conservación. Nordan Comunidad, Uruguay; 2001.

27. Friedman J, Yaniv Z, Dafni A, et al. A preliminary classification of the healing potential of medicinal plants, based on a rational analysis of an ethnopharmacological field survey among Bedouins in the Negev Desert, Israel. J Ethnopharmacol. 1986;16(2-3):275-287.

28. Alonso AS. De lo visible a lo invisible: sistema de salud intercultural entre los pueblos Tukano Oriental del Vaupes. in La diversidad ante el espejo: salud, interculturalidad y contexto migratorio. Abya Yala. 2008.

29. Pérez D. Etnobotánica medicinal y biocidas para malaria en la región Ucayali. Folia amazónica. 2002;13(1-2):87-108.

30. Pabon A, Ramirez O, Ríos A, et al. Antiplasmodial and Cytotoxic Activity of Raw Plant Extracts as Reported by Knowledgeable Indigenous People of the Amazon Region (Vaupes Medio in Colombia). Planta Med. 2016;82(8):717-722.

31. Ricker M, Veen G, Daly DC, et al. Alkaloid diversity in eleven species of Ormosia and in Clathrotropis macrocarpa (Leguminosae-Papilionoideae). Brittonia. 1994;46(4):355-371.

32. Sagen AL. Phytochemical and biological investigations on Clathrotropis glaucophylla (Fabaceae), an ingredient of Yanomamï curare, emphasizing on quinolizidine alkaloids. Diss Naturwissenschaften ETH Zürich, Switzerland; 2002

33. Forero Pinto E. Etnobotánica de las comunidades indígenas Waunana, Chocó (Colombia). Cespedesia. 1980;9(33):115-302.

34. Glenboski LL. Ethnobotany of the Tukuna Indians. Amazonas, Colombia; 1975.

35. Schultes RE, Raffauf RF. The healing forest: medicinal and toxic plants of the Northwest Amazonia. UNESCO, París (Francia); 1990;12:236-237.

36. Gachet MS, Lecaro JS, Kaiser M, et al. Assessment of anti-protozoal activity of plants traditionally used in Ecuador in the treatment of leishmaniasis.J Ethnopharmacol. 2010;128(1):184-197.

37. García Barriga H. Flora medicinal de Colombia. Bogotá DC: Instituto de Ciencias Naturales, Universidad Nacional de Colombia. 1974;3:443-459.

38. Gupta MPB. Plantas medicinales iberoamericanas. Bogotá DC, Colombia: Convenio Andrés Bello (CAB), Programa Iberoamericano de Ciencia y Tecnología (CYTED) y Universidad de Panamá. 2008.

39. Pérez-Arbeláez E. Plantas útiles de Colombia. DAMA, JBJCM, Bogotá, Colombia; 1996 
40. La Rotta C, Petei M, Nati Y, et al. Estudio Etnobotánico sobre las especies utilizadas por la Comunidad Indígena Miraña, Amazonas-Colombia. Bogotá DC: World Wildlife Fund, Bogota, Colombia; 1988. p. 386.

41. Milliken W. Traditional anti-malarial medicine in Roraima, Brazil. Economic Botany. 1997;51(3):212-237.

42. Moreira RDCT, Corrêa do Bomfim CL, Silva CRC, et al. Abordagem etnobotânica acerca do uso de plantas medicinais na Vila Cachoeira, Ilhéus, Bahia, Brasil. Acta farmacêutica bonaerense. 2002;21(3):205-211.

43. Odonne G, Bourdy G, Castillo D, et al. Ta'ta', Huayani: Perception of leishmaniasis and evaluation of medicinal plants used by the Chayahuita in Peru. Part II. J Ethnopharmacol. 2009;126(1):149-158.

44. Odonne G, Berger F, Stien D, et al. Treatment of leishmaniasis in the Oyapock basin (French Guiana): A K.A.P. survey and analysis of the evolution of phytotherapy knowledge amongst Wayapi Indians. J Ethnopharmacol. 2011;137(3):1228-1239.

45. Rodrigues E. Plants and animals utilized as medicines in the Jaú National Park (JNP), Brazilian Amazon. Phytother Res. 2006;20(5):378-391

46. Sanz-Biset J, Cañigueral S. Plant use in the medicinal practices known as "strict diets" in Chazuta valley (Peruvian Amazon). J Ethnopharmacol. $2011 ; 137(1): 271-288$.

47. Baluarte VJ, Valderrama FH. Contribución al conocimiento de la Anaueria sp. Añuje moena; nuevo registro en la Amazonía peruana. Folia Amazonica. 1990;2:1-16.

48. Tene V, Malagón O, Finzi PV, et al. An ethnobotanical survey of medicinal plants used in Loja and Zamora-Chinchipe, Ecuador. J Ethnopharmacol. 2007;111(1):63-81.

49. Sanz-Biset J, Campos-de-la-Cruz J, Epiquién-Rivera MA, et al. A firs survey on the medicinal plants of the Chazuta valley (Peruvian Amazon). J Ethnopharmacol. 2009;122(2):333-362.

50. Valadeau C, Castillo JA, Sauvain $M$, et al. The rainbow hurts my skin: medicinal concepts and plants uses among the Yanesha (Amuesha), an Amazonian Peruvian ethnic group. J Ethnopharmacol. 2010;127(1):175-192.

51. de Albuquerque UP, Muniz de Medeiros P, de Almeida AL, et al. Medicinal plants of the caatinga (semi-arid) vegetation of NE Brazil: a quantitative approach. J Ethnopharmacol. 2007;114(3):325-354.

52. Abad MJ, Bermejo P, Sanchez Palomino S, et al. Antiviral activity of some South American medicinal plants. Phytother Res. 1999;13(2):142-146.

53. de las Heras B, Slowing K, Benedí J, et al. Antiinflammatory and antioxidant activity of plants used in traditional medicine in Ecuador. $J$ Ethnopharmacol. 1998;61(2):161-166.

54. Bertania S, Bourdy G, Landau I, et al. Evaluation of French Guiana traditional antimalarial remedies. J Ethnopharmacol. 2005;98(1):45-54.

55. Deharo E, Bourdy G, Quenevo C, et al. A search for natural bioactive compounds in Bolivia through a multidisciplinary approach. Part V. Evaluation of the antimalarial activity of plants used by the Tacana Indians. J Ethnopharmacol. 2001;77(1):91-98.

56. Ruiz L, Ruiz L, Maco M, et al. Plants used by native Amazonian groups from the Nanay River (Peru) for the treatment of malaria. J Ethnopharmacol. 2011;133(2):917-921.

57. Kaur K, Jain M, Kaur T, et al. Antimalarials from nature. Bioorganic \& medicinal chemistry. 2009;17(9):3229-3256.

58. Kffuri CW, Lopes MA, Ming LC, et al. Antimalarial plants used by indigenous people of the Upper Rio Negro in Amazonas, Brazil. J Ethnopharmacol 2016;178:188-198.

59. Vigneron M, Deparis X, Deharo E, et al. Antimalarial remedies in French Guiana: a knowledge attitudes and practices study. J Ethnopharmacol. 2005;98(3):351-360.
60. Kinghorn AD, Chai HB, Sung CK, et al. The classical drug discovery approach to defining bioactive constituents of botanicals. Fitoterapia. 2011;82(1):71-79.

61. Calderon LdA, Silva-Jardim I, Zuliani JP, et al. Amazonian biodiversity: a view of drug development for leishmaniasis and malaria. J Braz Chem Soc. 2009;20(6):1011-1023.

62. Steele JC, Simmonds MS, Veitch NC, et al. Evaluation of the anti-plasmodial activity of bisbenzylisoquinoline alkaloids from Abuta grandifolia. Planta Med. 1999;65(5):413-416.

63. Garavito G, Rincón J, Arteaga L, et al. Antimalarial activity of some Colombian medicinal plants. J Ethnopharmacol. 2006;107(3):460-462.

64. Kvist LP, Christensen SB, Rasmussen HB, et al. Identification and evaluation of Peruvian plants used to treat malaria and leishmaniasis. $J$ Ethnopharmacol. 2006;106(3):390-402.

65. de Mesquita ML, Grellier P, Mambu L, et al. In vitro antiplasmodial activity of Brazilian Cerrado plants used as traditional remedies. J Ethnopharmacol. 2007;110(1):165-170.

66. Tabuti JR. Herbal medicines used in the treatment of malaria in Budiope county, Uganda. J Ethnopharmacol. 2008;116(1):33-42.

67. Asase A, Akwetey GA, Achel DG. Ethnopharmacological use of herbal remedies for the treatment of malaria in the Dangme West District of Ghana. J Ethnopharmacol. 2010;129(3):367-376.

68. Adebayo JO, Krettli AU. Potential antimalarials from Nigerian plants: a review. J Ethnopharmacol. 2011;133(2):289-302.

69. Ajaiyeoba EO, Oladepo O, Fawole OI, et al. Cultural categorization of febrile illnesses in correlation with herbal remedies used for treatment in Southwestern Nigeria. J Ethnopharmacol. 2003;85(2-3):179-185.

70. Koudouvo K, Karou DS, Kokou K, et al. An ethnobotanical study of antimalarial plants in Togo Maritime Region. J Ethnopharmacol. 2011;134(1):183-190.

71. Awe SO, Olajide OA, Oladiran OO, et al. Antiplasmodial and antipyretic screening of Mangifera indica extract. Phytother Res. 1998;12(6):437-438.

72. Ajaiyeoba $\mathrm{EO}$, Abiodun $\mathrm{OO}$, Falade $\mathrm{MO}$, et al. In vitro cytotoxicity studies of 20 plants used in Nigerian antimalarial ethnomedicine. Phytomedicine. 2006;13(4):295-298.

73. Antoun MD, Gerena L, Milhous WK. Screening of the Flora of Puerto Rico for Potential Antimalarial Bioactives. IJPPR. 1993;31(4):255-258.

74. Weniger B, Robledo S, Arango GJ, et al. Antiprotozoal activities of Colombian plants. J Ethnopharmacol. 2001;78(2-3):193-200.

75. Oga S, Sertié JA, Brasile AC, et al. Antiinflammatory effect of crude extract from Guarea guidonia. Planta Med. 1981;42(3):310-312.

76. Lago JHG, Brochini CB, Roque NF. Analysis of the Essential Oil from Leaves of Three Different Specimens of Guarea guidonia (L.) Sleumer (Meliaceae). Journal of Essential Oil Research. 2005;17(3):271-273.

77. Lago JHG, Brochini CB, Roque NF. Terpenoids from Guarea guidonia. Phytochemistry. 2002;60(4):333-338.

78. Garcez WS, Garcez FR, Soares LR. 16,17-Seco- and 2,3:16,17-di-Seco-pregnanes from Guarea guidonia. $J$ Braz Chem Soc. 2008;19(6):1073-1077.

79. Pohlit AM, Jabor VAP, Amorim RCN, et al. LC-ESI-MS determination of quassinoids isobrucein B and neosergeolide in Picrolemma sprucei stem infusions. J Braz Chem Soc. 2009;20(6):1065-1070.

80. de Andrade-Neto VF, Pohlit AM, Pinto AC, et al. In vitro inhibition of Plasmodium falciparum by substances isolated from Amazonian antimalarial plants. Mem Inst Oswaldo Cruz. 2007;102(3):359-365. 
81. Silva EC, Cavalcanti BC, Amorim RC, et al. Biological activity of neosergeolide and isobrucein B (and two semi-synthetic derivatives) isolated from the Amazonian medicinal plant Picrolemma sprucei (Simaroubaceae). Mem Inst Oswaldo Cruz. 2009;104(1):48-56.

82. Struwe L, Albert VA. A monograph of Neotropical potalia aublet (Gentianaceae: Potalieae). Systematic botany. 2004;29(3):670-701.

83. Duke J, R Vasquez. Amazonian Ethnobotanical Dictionary. FL: CRC Press, B Raton, USA; 1994.

84. Roumy V, Garcia-Pizango G, Gutierrez-Choquevilca AL, et al. Amazonian plants from Peru used by Quechua and Mestizo to treat malaria with evaluation of their activity. J Ethnopharmacol. 2007;112(3):482-489.

85. Gentry AH. Bignoniaceae, in Flora de Colombia, IdC Naturales. In: Forero E, Betancur J, editors. Universidad Nacional de Colombia, Bogotá DC, Colombia; 2009. p. 1-462.

86. Pinedo M, Rengifo E, Cerruti T. Plantas Medicinales de la Amazonía Peruana. Perú: Instituto de Investigaciones de la Amazonía Peruana (IIAP), Iquitos, Peru; 1997.

87. Cayón E, Aristizabal S. Etnobotánica Chamí. Cespedesia. 1980;9(33-34):5-114.

88. Roig JT. Plantas medicinales de Costa Rica y su folclore. UC Rica, editor. San José, Costa Rica, 1988. p. 103-104.

89. Ayensu ES. Medicinal Plants of the West Indies. Algonac, Michigan, USA; 1981. p. 282.

90. Díaz JL. Usos de las plantas medicinales de México. IMEPLAN, México; 1977. p. 345.

91. Morton JF. Atlas of Medicinal Plants of Middle America: Bahamas to Yucatan. Thomas CC, 1980. p. 1448.

92. Escobar N. Flora Tóxica de Panamá. U. Panamá, Panama. 1972.

93. Figueroa H. Enfermedades de los conquistadores. Ibarra JdP, Antigua, Guatemala. 1983.

94. Guzmán DJ. Especies útiles de la flora Salvadoreña. Md Educación, San Salvador, El Salvador. 1975.

95. Barrett B. Medicinal Plants of Nicaragua's Atlantic Coast. Economic Botany. 1994;48(1):8-20.
96. Agarwal K, Popli S. The constituents of Crescentia cujete leaves. Fitoterapia 1992;63(5):476.

97. Leonti M, Ramirez RF, Sticher O, et al. Medicinal Flora of the Popoluca, Mexico: A botanical systematical perspective. Economic Botany. 2003;57(2):218-230.

98. Aponte JC, Vaisberg AJ, Rojas R, et al. Isolation of cytotoxic metabolites from targeted peruvian amazonian medicinal plants. $J$ Nat Prod. 2008;71(1):102-105.

99. Fournet A, Barrios AA, Munoz V. Leishmanicidal and trypanocidal activities of Bolivian medicinal plants. J Ethnopharmacol. 1994;41(1-2):19-37.

100. Menachery MD. Chapter Three The alkaloids of south american menispermaceae. In: Pelletier SW, editor. Alkaloids: Chemical and Biological Perspectives. Pergamon, Turkey; 1996. p. 269-302.

101. Boster JS. Requiem for the omniscient informant: There's life in the old girl yet. In: Dougherty JWD, editor. Directions in cognitive anthropology. Chicago; 1985. p. 177-197.

102. Garro LC. Intracultural Variation in Folk Medical Knowledge: A Comparison Between Curers and Noncurers. American Anthropologist. 1986;88(2):351-370.

103. Gentry AH. A Synopsis of Bignoniaceae Ethnobotany and Economic Botany. Ann Mo Bot Gard. 1992. p. 79.

104. Matos FdA. Plantas medicinais: guia de seleção e emprego de plantas usadas em fitoterapia no Nordeste do Brasil. Plantas medicinais: guia de seleção e emprego de plantas usadas em fitoterapia no Nordeste do Brasil, Brasil; 2000.

105. Russo E, Reichelt AA, De-Sá JR, et al. Clinical trial of Myrcia uniflora and Bauhinia forficata leaf extracts in normal and diabetic patients. Braz J Med Biol Res. 1990;23(1):11-20.

106. Yadava R, Reddy VMS. Anti-inflammatory activity of a novel flavonol glycoside from the Bauhinia variegata Linn. Nat Prod Res. 2003;17(3):165-169.

107. Pokhrel NR, Adhikari RP, Baral MP. In-vitro evaluation of the antimicrobial activity of Bauhinia variegata, locally known as koiralo. World J Microbiol Biotechnol. 2002;18(1):69-71. 